\title{
INFLUENCE OF THE IMPACT ANGLE AND PRESSURE ON THE SPRAY COOLING OF VERTICALLY MOVING HOT STEEL SURFACES
}

\author{
VPLIV VPADNEGA KOTA IN TLAKA NA OHLAJANJE Z \\ BRIZGANJEM NA VERTIKALNO PREMIKAJOČE SE VROČE \\ POVRŠINE JEKLA
}

\author{
Milan Hnízdil, Martin Chabičovský, Miroslav Raudenský \\ Heat Transfer and Fluid Flow Laboratory, Brno University of Technology, Technicka 2896/2, 616 69 Brno, Czech Republic, European Union \\ hnizdil@fme.vutbr.cz \\ Prejem rokopisa - received: 2013-10-09; sprejem za objavo - accepted for publication: 2014-09-04
}

doi:10.17222/mit.2013.239

\begin{abstract}
The cooling of vertically moving strips is used very often to obtain the required material properties. Water spray cooling has to be used when a high cooling intensity is needed.

Our Heat Transfer and Fluid Flow Laboratory is equipped with a testing device which allows vertical movement of a heated experimental plate (sheet). Two different sizes of flat-jet nozzles were tested with different water pressures and angles of the water impact (inclination angles of the spraying bar). The water-pressure range was between 2 bar and 9.3 bar and the angle of the water impact changed from $20^{\circ}$ to $40^{\circ}$

The dependence of the heat-transfer coefficient on the surface temperature was evaluated for each experiment. Interesting results were obtained from the comparison of these experimental results, showing that the heat-transfer coefficient and the Leidenfrost temperature increase with the increasing water pressure. Very interesting results were obtained during the tests with different inclination angles. The highest heat-transfer coefficient was obtained for the angle of $20^{\circ}$ and the lowest value of the heat-transfer coefficient was obtained for the angle of $40^{\circ}$ at the surface temperatures of around $200{ }^{\circ} \mathrm{C}$.

Keywords: spray cooling, flat-jet nozzles, impact angle, water impingement density, Leidenfrost temperature
\end{abstract}

Ohlajanje vertikalno premikajočih se trakov se pogosto uporablja za zagotovitev zahtevanih lastnosti materiala. Kadar je potrebna velika intenzivnost hlajenja, se uporablja ohlajanje z brizganjem vode.

Laboratorij za prehajanje toplote in tok fluidov je opremljen s preizkusno napravo, ki omogoča vertikalno premikanje eksperimentalne plošče (jeklo). Preizkušeni sta bili dve različni dimenziji šob pri različnih tlakih vode in različnih kotih pršenja vode (nagibni kot palice za brizganje). Območje tlaka vode je bilo med 2 bar in 9,3 bar, kot vodnega curka pa med $20^{\circ}$ in $40^{\circ}$.

Za vsak poskus je bila ocenjena odvisnost koeficienta prehajanja toplote od temperature površine. Dobljeni so bili zanimivi rezultati iz primerjave eksperimentalnih podatkov, ki kažejo, da koeficient prehajanja toplote in Leidenfrostova temperatura naraščata $\mathrm{z}$ večanjem tlaka vode. Zanimive rezultate smo dobili tudi pri poskusih z različnimi vpadnimi koti. Najvišji koeficient prehajanja toplote je bil dosežen pri kotu $20^{\circ}$, najnižja vrednost koeficienta prehajanja toplote pa je bila dosežena pri kotu $40^{\circ}$ pri temperaturi površine okrog $200{ }^{\circ} \mathrm{C}$.

Ključne besede: hlajenje z brizganjem, šobe s ploščatim curkom, vpadni kot curka, gostota udarca vode, Leidenfrostova temperatura

\section{INTRODUCTION}

Vertically moving strips are cooled by spraying water when a high cooling intensity (the heat-transfer coefficient) is needed. The cooling of these strips has to be homogeneous to avoid thermal deformation. Falling reflected water has a significant influence on the cooling homogeneity ${ }^{1}$. It can cause local thermal stresses in a strip and its deformation. The heat-transfer coefficient is influenced by many parameters such as water pressure, nozzle distance, water impingement density, water temperature, etc. ${ }^{2-4}$

A special cooling system which sprays water at a prescribed inclination angle to avoid the falling of the reflected water (Figure 1) was tested and the influence of the impact angle and the pressure on the heat-transfer coefficient was investigated during the cooling of a stainless-steel sheet at the initial temperature of $900{ }^{\circ} \mathrm{C}$.
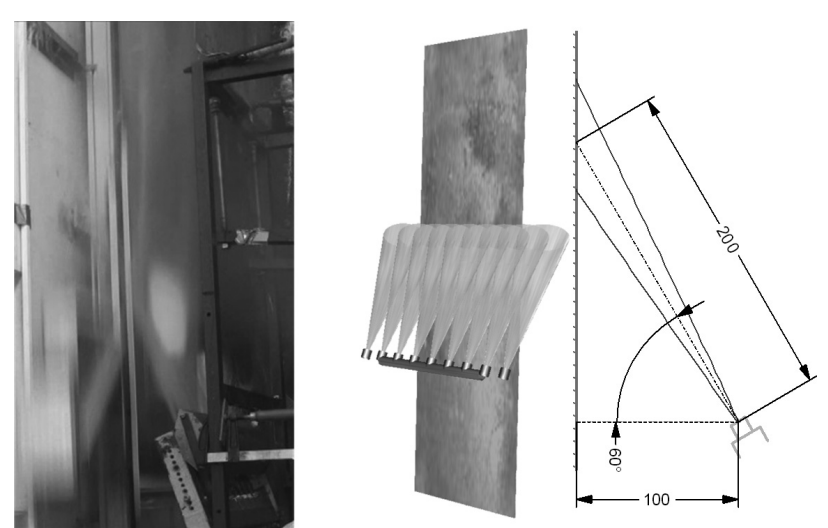

Figure 1: Cooling system (inclination angle of $30^{\circ}$, distance to the surface is $100 \mathrm{~mm}$ )

Slika 1: Sistem ohlajanja (vpadni kot $30^{\circ}$, razdalja do površine 100 $\mathrm{mm}$ ) 


\section{LABORATORY STAND, EXPERIMENTAL PROCESS AND CONFIGURATION}

An experimental apparatus developed for the vertical moving of a hot stainless-steel test sheet was used in the experiments (Figure 2). An electrical furnace which heated the experimental sheet to its initial temperature was positioned in the upper part of the testing bench. This sheet was made of thick austenitic stainless steel 1.5 $\mathrm{mm}$. Five thermocouples were welded to the rear side of the sheet and they were positioned in the center line, perpendicular to the direction of the movement of the sheet. The test sheet was fixed on the trolley which moved repeatedly through the water spray. The temperatures were recorded by a data logger with a frequency of 320 $\mathrm{Hz}$ for each thermocouple.

The experiments started by heating the sheet in an inert atmosphere to the initial temperature $\left(900{ }^{\circ} \mathrm{C}\right)$. Then the required water pressure was set. The data logger was switched on and it started to record the temperatures. Then the test sheet repeatedly moved through the spray till the surface temperature was less than 200 ${ }^{\circ} \mathrm{C}$.

The recorded data were transferred to a computer and the inverse $\operatorname{task}^{5}$ was used to compute the surface temperature, the heat flux and the heat-transfer coefficient, which is usually used as a boundary condition ${ }^{6}$.

The influence of the water pressure was investigated. Five tests, each with a different water pressure $(2,4,6,8$

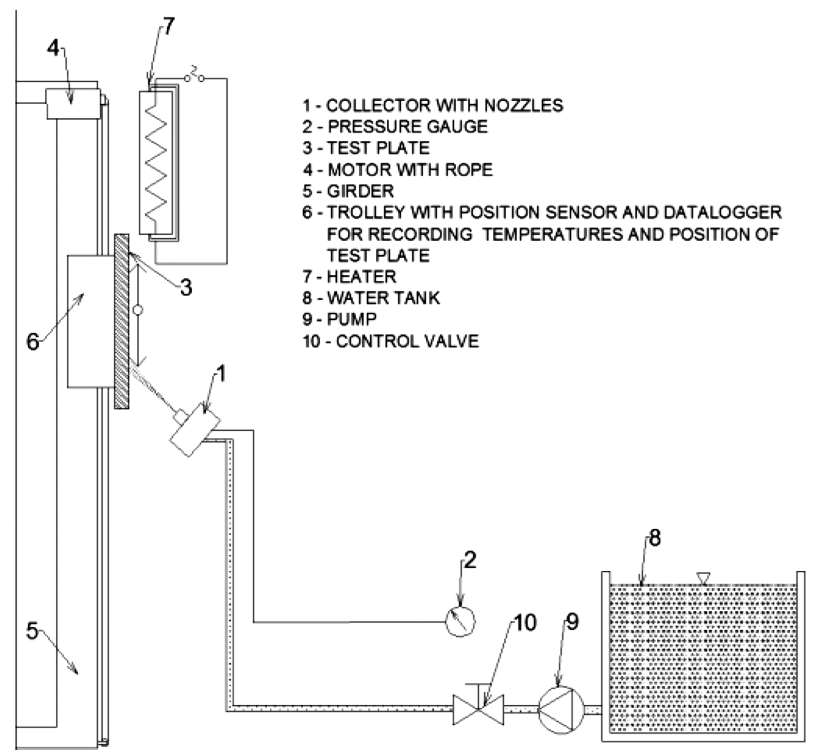

Figure 2: Testing bench for experimental tests of cooling vertically moving strips ( 1 - collector with nozzles; 2 - pressure gauge; 3 - test plate; 4 - motor with rope; 5 - girder; 6 - trolley with position sensor and data logger for recording temperatures and position of the test plate; 7 - heater; 8 - water tank; 9 - pump; 10 - control valve)

Slika 2: Preizkusna klop za preizkušanje ohlajanja vertikalno premikajočih se trakov (1 - nosilec s šobami; 2 - merilnik tlaka; 3 preizkusna plošča; 4 - motor z vrvjo, 5 - nosilec; 6 - voziček s senzorjem pozicije in "data logger" za registracijo temperature ter pozicije preizkusne plošče; 7 - grelnik; 8 - vodni rezervoar; 9 črpalka; 10 - kontrolni ventil) and 9.3) bar, were conducted. Commercially available flat-jet nozzles were fixed in a single row with the same offset angle. The distance between the nozzles was 55 $\mathrm{mm}$. The distance of the nozzle orifices to the test sheet was $100 \mathrm{~mm}$ and the inclination angle was $20^{\circ}$ during these tests.

Further, three tests, each with a different inclination angle $\left(20^{\circ}, 30^{\circ}\right.$ and $40^{\circ}$ from the vertical direction, Figure 1) were conducted to investigate the influence of the inclination angle. These nozzles had a larger size of the orifice than the nozzles used for the tests with different water pressures. The distance between the nozzles was $100 \mathrm{~mm}$. The distance of the nozzle orifices to the test sheet was $100 \mathrm{~mm}$ and the water pressure was 4 bar during these experiments. All the experiments were conducted with the velocity of the movement of $3 \mathrm{~m} / \mathrm{s}$.

\section{RESULTS}

The results shown in this part are the average values of the heat-transfer coefficient in the impact area computed for the positions of $0 \mathrm{~mm}$ to $600 \mathrm{~mm}$ (Figure 3). The measured dependences of the heat-transfer coefficient on the surface temperature are shown for different water pressures (Figure 4a) and for different inclination angles (Figure 4b).

It is evident that the heat-transfer coefficient increases with the increasing water pressure (an increase in the water pressure also causes an increase in the water impingement density $\dot{m}_{\mathrm{L}}$ ). Also, the Leidenfrost temperature $\left(T_{\text {Leid }}\left({ }^{\circ} \mathrm{C}\right)\right)$, which is defined as the temperature at which the heat flux reaches its minimum (or the temperature, at which the film-boiling regime changes to the transition-boiling regime), increases with the increase in the pressure (Figure 5). The measured Leidenfrost temperatures are higher than the ones predicted

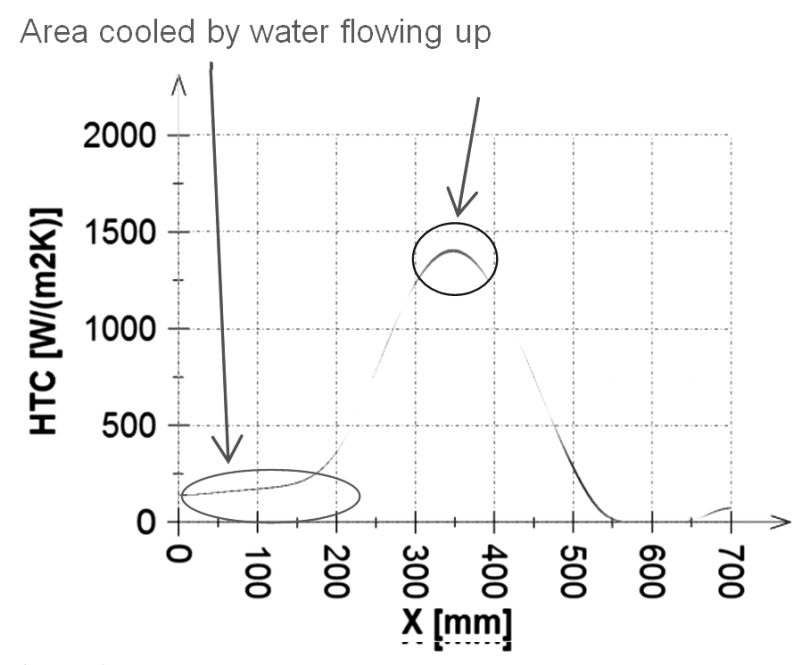

Figure 3: Dependence of the HTC on the position, for the surface temperature of $800{ }^{\circ} \mathrm{C}$ - evaluating area of $0-600 \mathrm{~mm}$

Slika 3: Odvisnost HTC od položaja pri temperaturi površine $800{ }^{\circ} \mathrm{C}$ - področje ocenjevanja 0-600 $\mathrm{mm}$ 

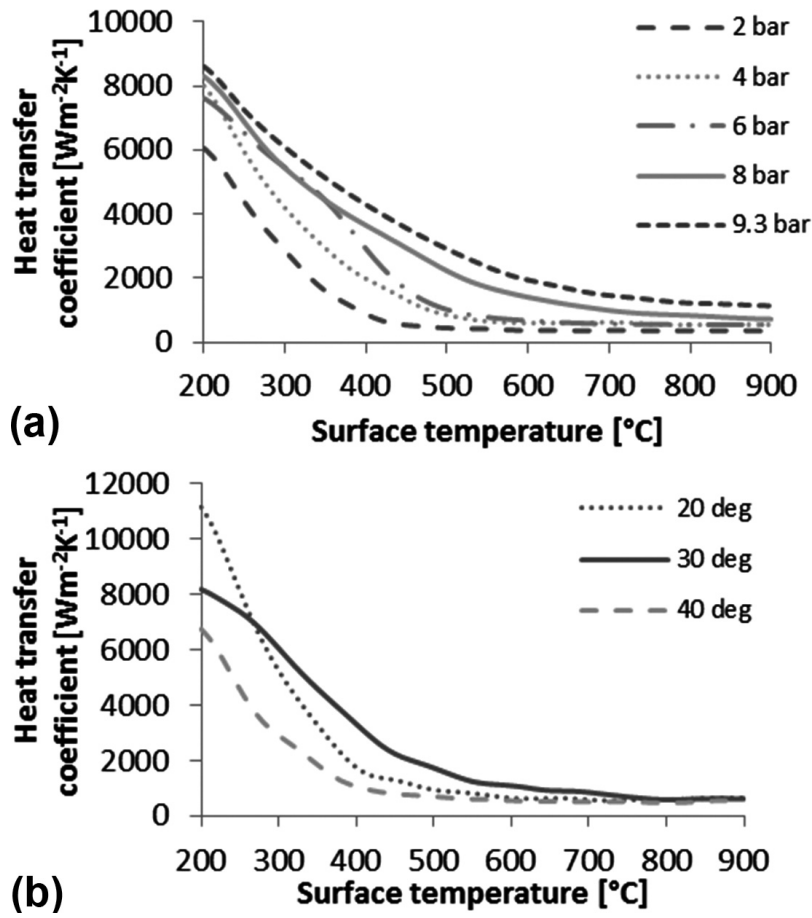

Figure 4: Dependence of the heat-transfer coefficient on the surface temperature for the: a) increasing water pressure and b) increasing inclination angle

Slika 4: Odvisnost koeficienta prehoda toplote od temperature površine pri: a) naraščajočem tlaku vode in b) naraščajočim vpadnim kotom

with the common prediction equations that use the water impingement density ${ }^{7,8}$ :

$$
\begin{aligned}
T_{\text {Leid }} & =339.604 \dot{m}_{\mathrm{L}}^{0.19} \\
T_{\text {Leid }} & =1400 \frac{\dot{m}_{\mathrm{L}}^{2} d_{32}^{0.13}}{\rho \sigma}
\end{aligned}
$$

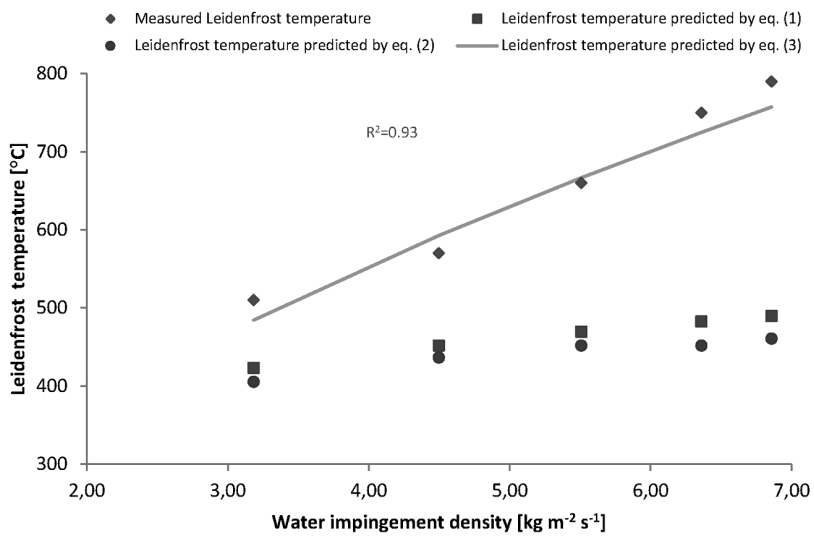

Figure 5: Comparison of the measured Leidenfrost temperature with the existing predictions and the new modified prediction of the Leidenfrost temperature (corresponding water impingement densities for water pressures of $(2,4,6,8$ and 9.3$)$ bar are $(3.18,4.5,5.51,6.36$ and 6.86) $\mathrm{kg} \mathrm{m}^{-2} \mathrm{~s}^{-1}$ )

Slika 5: Primerjava izmerjene Leidenfrostove temperature $\mathrm{z}$ obstoječim predvidevanjem in novo modificirano predvidevanje Leidenfrostove temperature (ustrezne gostote vodnega curka pri tlakih vode $(2,4,6,8$ in 9,3$)$ bar so $(3,18,4,5,5,51,6,36$ in 6,86$\left.) \mathrm{kg} \mathrm{m}^{-2} \mathrm{~s}^{-1}\right)$ where $\dot{m}_{\mathrm{L}}$ is the water impingement density $\left(\mathrm{kg} \mathrm{m}^{-2} \mathrm{~s}^{-1}\right)$, $d_{32}$ is the Sauter mean diameter $(\mathrm{m})$ of water droplets, $\rho$ is the density $\left(\mathrm{kg} \mathrm{m}^{-3}\right)$ and $\sigma$ is the surface tension $\left(\mathrm{N} \mathrm{m}^{-1}\right)$.

The comparison of the measured Leidenfrost temperatures and the ones predicted with Eqs. (2) and (3) is shown in Figure 5. The error of prediction with Eqs. (2) and (3) is growing with the increase in the pressure. This shows that the water pressure must be taken into account when an accurate prediction of the Leidenfrost temperature is necessary. The increase in the pressure increases the exit velocity of the water from a nozzle and this leads to destroying the vapour layer at higher surface temperatures. The new prediction of the Leidenfrost temperature based on Eq. (1) that takes the pressure into account is:

$$
T_{\text {Leid }}=339.604\left(\dot{m}_{\mathrm{L}} p\right)^{0.19}
$$

where $\dot{m}_{\mathrm{L}}$ is the water impingement density $\left(\mathrm{kg} \mathrm{m}^{-2} \mathrm{~s}^{-1}\right)$ and $p$ is the water pressure (bar).

The comparison of the new prediction with the measured data and the other predictions is shown in Figure 5.

The second part of the experiments was focused on the influence of the water impact angle on the cooling intensity. As it is shown in Figure $\mathbf{4 b}$, the heat-transfer coefficient and the Leidenfrost temperature are influenced by the change in the impact angle. The Leidenfrost temperature is the highest for the impact angle of $30^{\circ}$ $\left(800^{\circ} \mathrm{C}\right)$ and the lowest for the impact angle of $40^{\circ}$ $\left(540{ }^{\circ} \mathrm{C}\right)$. The Leidenfrost temperature for the impact angle of $20^{\circ}$ is $610^{\circ} \mathrm{C}$. The heat-transfer coefficient in the area of stable film boiling (the surface temperatures are higher than the Leidenfrost temperature - higher than $800{ }^{\circ} \mathrm{C}$ ) is almost the same for all the impact angles. The main effect of the inclination angle on the heat-transfer coefficient occurs at low surface temperatures (approximately $200^{\circ} \mathrm{C}$ ), where the heat-transfer coefficient is the highest at the angle of $20^{\circ}$ and the lowest at $40^{\circ}$.

\section{CONCLUSION}

Two kinds of tests were done to find the influence of the water pressure (the flow rate) and the impact angle on the heat-transfer coefficient. It is evident (from the results) that the cooling intensity increases with the increasing water-flow rate (the water pressure). Also, the Leidenfrost temperature is dependent on the water pressure - a higher water pressure means a higher leidenfrost point. Different spray impact angles cause changes in the heat-transfer coefficient at low surface temperatures and the Leidenfrost temperature also depends on the impact angle. A new correlation for the prediction of the leidenfrost temperature was found. 


\section{HNÍZDIL et al.: INFLUENCE OF THE IMPACT ANGLE AND PRESSURE ...}

\section{Acknowledgement}

This work is an output of research and scientific activities of the project LO1202 with financial support of the MEYS under the programme NPU I and the internal grant of the Brno University of Technology focused on specific research and development No. FSI-S-14-2437 and by the project No. CZ.1.07/2.3.00/20.0188, HEATEAM - Multidisciplinary Team for Research and Development of Heat Processes.

\section{REFERENCES}

${ }^{1}$ M. Chabicovsky, M. Raudenský, Experimental investigation of spray cooling of horizontally and vertically oriented surfaces, Conference proceedings of 22nd Conference on metallurgy and materials 1 , Ostrava, 2013, 102-107
${ }^{2}$ M. Chabicovsky, M. Raudenský, Experimental Investigation of the Heat Transfer Coeficient, Mater. Tehnol., 47 (2013) 3, 395-398

${ }^{3}$ M. Raudenský, M. Hnízdil, P. Kotrbáček, Why oxides intensify spray cooling, 30th International Steel Industry Conference, Paris, 2012, 92-337

${ }^{4}$ M. Hnízdil, M. Raudenský, Influence of Water Temperature on the Cooling Intensity during Continuous Casting and Hot Rolling, Conference METAL 2012, Brno, 2012, 1-6

${ }^{5}$ M. Raudenský, Heat Transfer Coefficient Estimation by Inverse Conduction Algorithm, International Journal of Numerical Methods for Heat and Fluid Flow, 3 (1993) 3, 257-266, doi:10.1108/eb017530

${ }^{6}$ J. Stetina, F. Kavicka, T. Mauder, Heat Transfer Coefficients Beneath the Water Cooling Nozzles of a Billet Caster, 18th International Conference on Metallurgy and Materials, Hradec Nad Moravici, 2009

${ }^{7}$ H. Muller, R. Jeschars, Wärmeübergang bei der Spritzwasserkühlung von Nichteisenmetallen, Metallkunde, 1983, 257-264

${ }^{8}$ S. Yao, T. L. Cox, A general heat transfer correlation for impacting water sprays on high-temperature surfaces, Experimental Heat Transfer, 15 (2002) 4, 207-219, doi:10.1080/08916150290082649 